\title{
Intensification of loosening of asbestos fibers by means of hydromechanical processing
}

\author{
O.M. Obodovich ${ }^{1}$ (ORCID 0000-0003-2230-1034), O.M. Nedbailo ${ }^{1}$ (ORCID 0000-0003-1416-9651), \\ O.G. Chernyshyn ${ }^{2}$ (ORCID 0000-0001-7702-894X), A.E. Nedbailo ${ }^{1}$ (ORCID 0000-0002-8590-5823) \\ ${ }^{1}$ - Institute of Engineering Thermophysics of NAS of Ukraine, str. Bulakhovskogo, 2, Bldg. 2, Kyiv, 03164, Ukraine \\ Tel.: +380444243185, +380444242527 \\ E-mail:tdsittf@ukr.net,nan_sashulya@ukr.net \\ 2 - The State Enterprise "Engineering Center "Drying”, Institute of Engineering Thermophysics of NAS of Ukraine, \\ str. Bulakhovskogo, 2, Bldg. 2, Kyiv, 03164, Ukraine \\ Tel.: +380444240279, tel./fax +380444243283 \\ E-mail:icsushka@gmail.com
}

Article info: received 11.03.2021, revised 24.03.2021, accepted 30.03.2021

Obodovich, O.M., Nedbailo, O.M., Chernyshyn, O.G., Nedbailo, A.E. (2021) Intensification of loosening of asbestos fibers by means of hydromechanical processing 1(50), DOI: 10.26909/csl.1.2021.4

Acceptance of high-quality aqueous suspensions based on chrysotile asbestos is an urgent technical task in a number of industries. Asbestos-cement mortar is used as an asbestos-cement crust for insulation of walls and other building surfaces, due to this composition of the treated surfaces perfectly retain heat, resistant to moisture, and most importantly - asbestos fibers contribute to the smoothness of the surface and crack is not formed. No less popular is the use of asbestos-cement mortar with a high content of asbestos in the insulation of ventilation ducts and pipelines. This composition of asbestos-cement mortar is used to strengthen the joints of asbestos-cement pipes, as well as as a filler in the laying of cast iron pipes to give the joints additional elasticity.

Asbestos-cement mortar has plasticity, resistance to stretching and reinforcement of asbestos, as well as strength and versatility in the use of cement. Due to these properties, asbestos and cement perfectly adhere to each other to obtain a durable, strong, frost-resistant, virtually waterproof and fire-resistant building material.

The result of the microscopic examination is reason to believe that from the technological process of production of slate can be removed electromechanical mixer for the preparation of a solution of asbestos + water + portland cement. In this case, given the fact of continued loosening of asbestos in the preparation of the mold mixture of asbestos + water + portland cement, it will be sufficient to ensure the degree of loosening of asbestos in the ripper at the minimum required level (for example, not more than $85 \%$ ). It is assumed to obtain a mold mixture with a high degree of homogeneity of the components with reduced costs of Portland cement due to its physico-chemical activation by hydraulic fluxes.

Key words: asbestos-cement, loosening of asbestos fibers, mixture of asbestos + water + portland cement.

\section{Інтенсифікація розпушування азбестових волокон за допомогою гідромеханічного оброблення}

\author{
О.М. Ободович ${ }^{1}$, О.М. Недбайлоㄹ, О.Г. Чернишин ${ }^{2}$, А.С. Недбайло ${ }^{1}$ \\ 1 - Інститут технічної теплофізики НАН Украӥни, Київ, Украӥна \\ 2 - Державне підприємство «Інженерний цеентр «Сушка»» Інституту технічної теплофізики НАН України, \\ Київ, Україна
}

Приготування високоякісних водних суспензій на основі хризотилового азбесту є актуальним технічним завданням у ряді галузей промисловості. Азбестоцементний розчин застосовується, після його висихання, як тверда кірка для утеплення стін та інших будівельних поверхонь. Завдяки такому складу оброблені поверхні набувають теплоізоляційних властивостей, стають стійкими до вологи та запобігають утворенню тріщин на 
поверхні. Не менш популярним є використання азбестоцементного розчину з високим вмістом азбесту в ізоляції вентиляційних каналів і трубопроводів. Цей склад азбестоцементного розчину застосовується для зміцнення стиків азбестоцементних труб, а також як заповнювач при прокладанні чавунних труб для додання стикам додаткової еластичності.

Азбестоцементний розчин має прийнятні пластичність, стійкість до розтягування та армування азбестом, а також міцність і універсальність при використанні цементу. Завдяки цим властивостям азбест та цемент задовільно злипаються один з одним, отримуючи міцний, морозостійкий, практично водонепроникний та вогнестійкий будівельний матеріал.

Результат мікроскопічного дослідження є підставою вважати, що з технологічного процесу виробництва шиферу може бути вилучений електромеханічний змішувач для приготування розчину азбесту + вода + портландцемент. У цьому випадку, враховуючи факт продовження розпушування азбесту при приготуванні формової суміші азбест + вода + портландцемент, буде достатньо забезпечити ступінь розпушування азбесту в розпушувачі на мінімально необхідному рівні (наприклад, не більше 85 \%). Передбачається отримання формової суміші з високим ступенем однорідності компонентів із зниженими витратами портландцементу внаслідок його фізико-хімічної активації гідравлічними потоками.

\section{Ветуп}

Волокнисті компоненти є головним структуроутворюючим елементом низки пористих та суцільних композиційних матеріалів різноманітного призначення. Одним із розповсюджених природних волокнистих мінералів $є$ хризотил-азбест (XА). Існують два різновиди керамічних виробів, що містять азбест. Їхня назва відображає наявну в ній кількість азбесту: кераміка, що містить 50 - 60 \% азбесту називається азбестовою керамікою; матеріали, що містять $90 \%$ азбесту і до $10 \%$ глини є виробами 3 азбесту.

До композиційних матеріалів з волокнистим армуванням належать склоцементні, склопластикові та азбестоцементні. Як способи армування можуть використовуватись направлене і хаотичне. В цих матеріалах використовують різні матричні в'яжучі й армуючі компоненти. Продукція азбестоцементної промисловості є різноманітною, але їй притаманні особливості структуроутворення при водонасиченні та сушінні. До сучасних композиційних матеріалів належать, в тому числі, дисперсно-армовані. Фізико-механічні та теплотехнічні властивості фібробетону залежать від концентрації фібри у складі композиційного матеріалу, а ефективність експлуатації фібробетонів у конструкціях - від зменшення працезатрат на арматурні роботи, скорочення витрат сталі та бетону, підвищення довговічності, зниження затрат на ремонтні роботи, суміщення технологічних операцій приготування бетонної суміші та армування.

Азбестоцементний розчин застосовується, після його висихання, як тверда кірка для утеплення стін та інших будівельних поверхонь. Завдяки такому складу оброблені поверхні набувають теплоізоляційних властивостей, стають стійкими до вологи та запобігають утворенню тріщин на поверхні. Не менш популярним є використання азбестоцемент- ного розчину з високим вмістом азбесту в ізоляції вентиляційних каналів і трубопроводів. Цей склад азбестоцементного розчину застосовується для зміцнення стиків азбестоцементних труб, а також як заповнювач при прокладанні чавунних труб для додання стикам додаткової еластичності.

Азбестоцементний розчин має прийнятні пластичність, стійкість до розтягування та армування азбестом, а також міцність і універсальність при використанні цементу. Завдяки цим властивостям азбест та цемент задовільно злипаються один $з$ одним, отримуючи міцний, морозостійкий, практично водонепроникний та вогнестійкий будівельний матеріал.

Метою роботи є попередній аналіз технологічності використання композитних азбестовмістних матеріалів, що побудований на результатах мікроскопічного дослідження структури азбестових волокон після їх гідромеханічного оброблення. Приготування якісних водних суспензій на основі хризотил-азбесту є актуальною технічною задачею в ряді галузей промисловості.

\section{Матеріали та методи дослідження}

Більш ніж 30 років тому назад було встановлено, що високошвидкісні гідродинамічні потоки, що створюються у водній суспензії ХА із концентрацією 1 - 4 мас. \%, призводять до отримання дисперсних систем (ДС) із високою агрегативною стійкістю. Проте, внаслідок впливу низки, непереборних на той час, чинників, ефективний імпульсний спосіб оброблення суспензій ХА не отримав промислового застосування при розв'язанні, наприклад, задач у галузі будівельного матеріалознавства [1].

В Інституті технічної теплофізики Національної академії наук України (ІТТФ НАН України) протягом останніх років проводяться комплексні дослідження процесів тепло- і масообміну та гідро- 
механічних процесів в рідких багатокомпонентних середовищах різної концентрації. Ці дослідження безпосередньо пов'язані 3 інтенсифікацією технологічних процесів подрібнення різноманітних об'єктів природного та штучного походжень.

На відміну, наприклад, від розрядно-імпульсного способу перетворення енергії запропонований в [2] гідромеханічний спосіб дозволяє ініціювати режими оброблення середовища, за яких не відбувається руйнівної деструкції елементів дисперсної фази. Результатом виконання таких робіт є розробка запатентованих в Україні технологій та пристроїв, що їх реалізують, для процесів диспергування [2]. У порівнянні 3 традиційними промисловими способами приготування якісних ДС технологія гідромеханічної активації $\epsilon$ енерго- та ресурсозберігаючою, що за питомими енерговитратами та за якістю кінцевого продукту, в багатьох випадках, переважає показники існуючих вітчизняних і закордонних технологій.

Однією з таких технологій є диспергування, що реалізується обладнанням системи гідродинамічного пульсатора. Принципову схему однієї з різновидностей гідравлічного пульсатора зображено на рис. 1. Апарат складається з резервуару 1 , джерела стисненого повітря 2, джерела вакууму 3 і пульсатора 4, що розділений двома гнучкими мембранами 5 на три ємності, бокові з яких за допомогою трубопроводу 6 та клапанів 7 і 8 з'єднані $з$ джерелом стисненого повітря 2 та джерелом вакууму 3 , а середня ємність обладнана трубою 9, нижня частина якої опущена до резервуару 1.

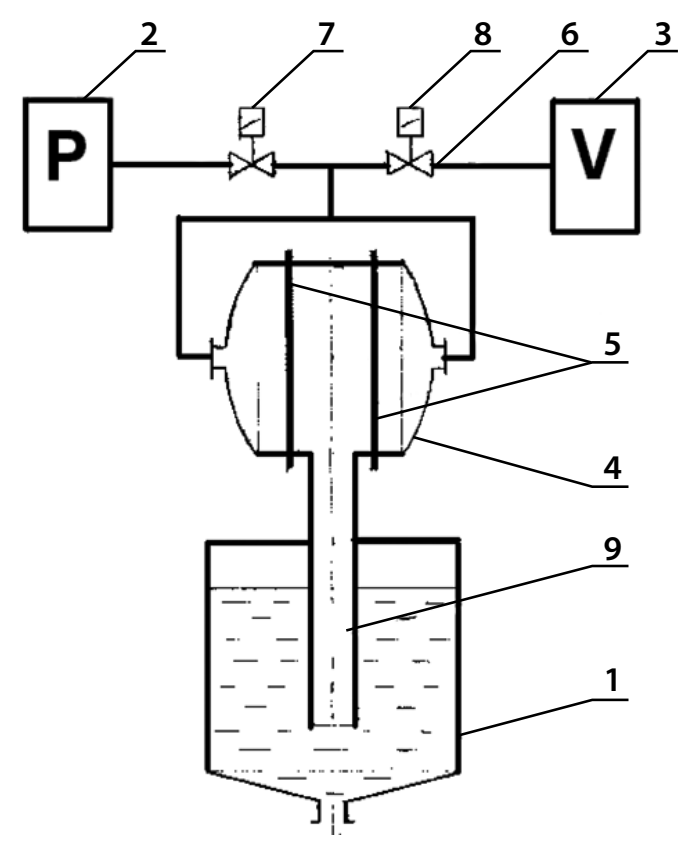

Рис. 1. Принципова схема гідродинамічного пульсатора
Апарат працює наступним чином. Клапани 7 і 8 відчиняються почергово в противофазі. Якщо клапан 7 зачинений, то клапан 8 - відчинений, і при цьому бокові ємності пульсатора 4 з'єднуються 3 джерелом вакууму 3, під дією якого гнучкі мембрани 5 розводяться, утворюючи в середній ємності пульсатора 4 розрідження, внаслідок чого суміш 3 резервуару 1 по трубі 9 втягується в середню ємність пульсатора 4. Після цього клапан 8 зачиняється, а клапан 7 відчиняється і з'єднує бокові ємності пульсатора 4 із джерелом стисненого повітря 2, під дією якого в бокових ємностях пульсатора 4 створюється надлишковий, у порівнянні $з$ середньою ємністю пульсатора 4, тиск. Внаслідок цього гнучкі мембрани 5 зводяться і з силою виштовхують суміш по трубі 9 з середньої ємності пульсатора 4 в резервуар 1. Далі цикл багатократно повторюється [2].

В ініціативному порядку в ІТТФ НАН України виконані пошукові експерименти щодо отримання суспензій ХА + вода (вода $3 \mathrm{pH}=7,0$ і температурою $\left.15-17^{\circ} \mathrm{C}\right) 3$ метою подальшого їх використання у технології виробництва композиційних матеріалів, зокрема шиферу згідно ДСТУ Б В.2.7-52-96 (ГОСТ 18124-95) «Листи азбестоцементні пласкі. ТУ» та ДСТУ Б В.2.7-53-96 (ГОСТ 30340-95) «Листи азбестоцементні хвилясті. ТУ».

Лабораторне обладнання є міні-аналогом енергоощадного обладнання системи «Промисловий гідродинамічний пульсатор». Ця розробка ІТТФ НАН України раніше була впроваджена у нафтогазовій промисловості для приготування глиняних суспензій разовим об'ємом до 4 м $^{3}[3,4]$.

Якість розпушування азбесту (концентрація

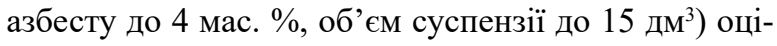
нювали за допомогою промислової методики, що була надана раніше Київським шиферним заводом (агрегативна стійкість суспензії розпушеного азбесту при концентрації 0,5 мас. \%; тривалість оцінювання - 30 хв.) та оптичного мікроскопу.

В результаті експериментів було встановлено, що гідродинамічний пульсатор дозволяє отримати ступінь розпушування азбесту до 99 \% за методикою, що використовується на Київському шиферному заводі (за регламентом ступінь розпушування повинна бути не нижчою за 98 \%). Мікроскопічні дослідження підтвердили відсутність нерозпушених фібрил та наявність переподрібнених елементарних волокон (рис. 2).

\section{Висновки}

Отримані мікроскопічні дані досліджень дозволяють зробити наступні попередні висновки:

1. За визначеної продуктивності та зменшених на $12 \%$ енергетичних витратах (у порівнянні з іс- 

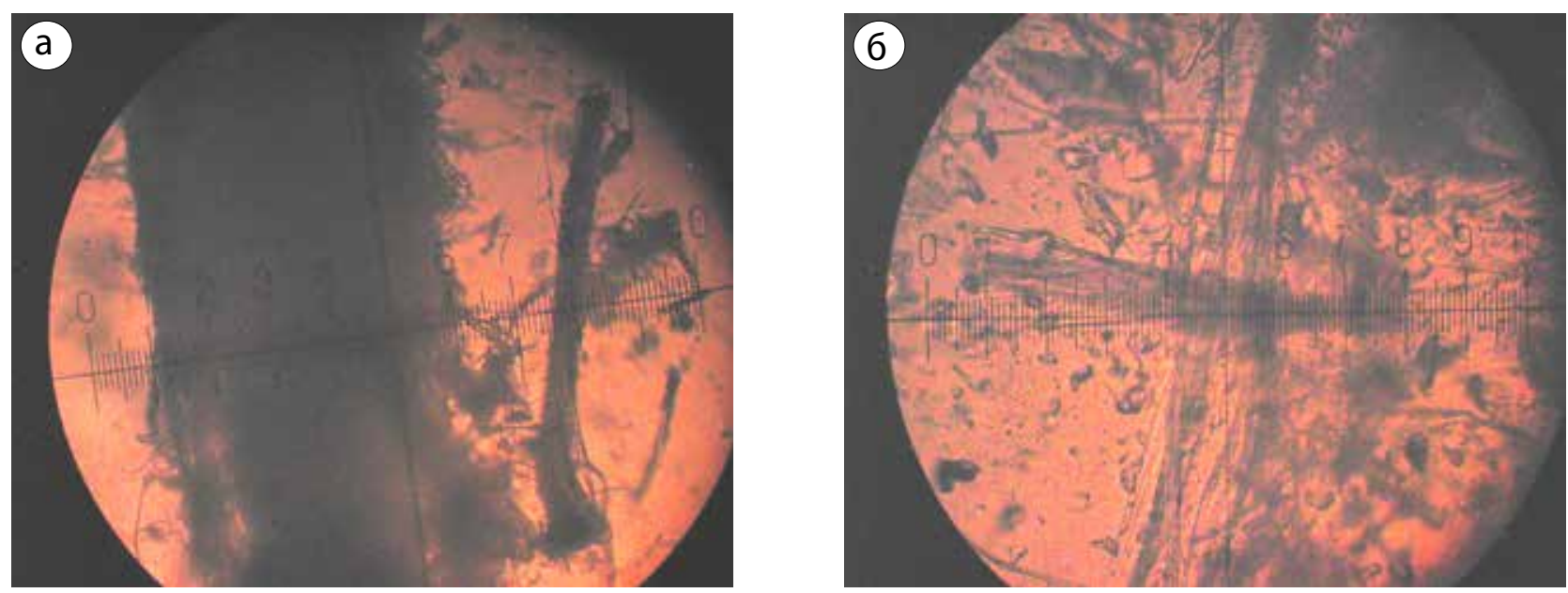

Рис. 2. Структура азбестових волокон до (а) та після (б) оброблення на гідродинамічному пульсаторі.

Одна поділка мікроскопа - 4 мкм

нуючими питомими витратами енергії на виробництво одиниці продукції, наприклад, на Київському шиферному заводі) промисловий гідродинамічний пульсатор дозволить отримувати формову суміш азбест + вода + портландцемент за технологічно заданий час (тривалість процесу до 20 хв.).

2. Результат мікроскопічного дослідження $\epsilon$ підставою вважати, що з технологічного процесу виробництва шиферу може бути вилучений електромеханічний змішувач для приготування розчину азбесту + вода + портландцемент. У цьому випадку, враховуючи факт продовження розпушування азбесту при приготуванні формової суміші азбест + вода + портландцемент, буде достатньо забезпечити ступінь розпушування азбесту в розпушувачі на мінімально необхідному рівні (наприклад, не більше 85 \%). Передбачається отримання формової суміші з високим ступенем однорідності компонентів із зниженими витратами портландцементу внаслідок його фізико-хімічної активації гідравлічними потоками.

3. Не виключено також, що при забезпеченні заданої середньої щільності та міцністних харак- теристик шиферу буде зменшений вміст азбесту у складі шиферу.

\section{References}

1. Опєкунов, В.В. Конструкційно-теплоізоляційні будівельні матеріали на основі активованих сировинних компонентів. - К.: Академперіодика. 2001. $-216 \mathrm{c}$.

2. Масообмінний пристрій: А.с. 58295. Україна. МКВ А 7 В 01 D 11/04, В 01 F 3/08 / А.А. Долінський, О.А. Корчинський, А.П. Гартвіг, М.В. Матюшкін. Опубл. 15.07.2003, Бюл. № 7.

3. Иваницкий, Г.К., Корчинский, А.А., Матюшкин, M.B. Математическое моделирование процессов в пульсационном диспергаторе ударного типа. Проблемы промышленной теплотехники. - Киев. №1, 2003. - С. 29 - 34.

4. Мартиненко, I.I., Корчинський, О.А., Матюшкін, М.В., Корняга, Ф.В., Непомнящий, А.С. Приготування бурових розчинів за методом імпульсного введення дискретних порцій енергії. Нафтова та газова промисловість, №5. - 1999. - С. 30 - 32. 